\title{
Importance of prostate androgen-regulated mucin-like protein 1 in development of the bovine blastocyst
}

\author{
Adriana M. Zolini ${ }^{1,2}$, Verónica M. Negrón-Pérez ${ }^{1,2}$ and Peter J. Hansen ${ }^{1 *}$ (D)
}

\begin{abstract}
Background: Prostate androgen-regulated mucin-like protein 1 (PARM1) is a pro-proliferative and anti-apoptotic glycoprotein involved in the endoplasmic reticulum (ER) stress response. A single nucleotide polymorphism in the coding region of PARM1 has been associated with competence of bovine embryos to develop to the blastocyst stage. Here we tested the importance of PARM1 for development by evaluating consequences of reducing PARM1 mRNA abundance on embryonic development and differentiation, gene expression and resistance to ER stress.

Results: Knockdown of PARM1 using an anti-PARM1 GapmeR did not affect competence of embryos to develop into blastocysts but decreased the number of trophectoderm (TE) cells in the blastocyst and tended to increase the number of cells in the blastocyst inner cell mass (ICM). Treatment of embryos with anti-PARM1 GapmeR affected expression of 4 and 3 of 90 genes evaluated at the compact-morula and blastocyst stage of development at days 5.5 and 7.5 after fertilization, respectively. In morulae, treatment increased expression of DAB2, INADL, and STAT3 and decreased expression of CCR2. At the blastocyst stage, knockdown of PARM1 increased expression of PECAM and TEAD4 and decreased expression of CCR7. The potential role of PARM1 in ER stress response was determined by evaluating effects of knockdown of PARM1 on development of embryos after exposure to heat shock or tunicamycin and on expression of ATF6, DDIT3 and EIF2AK3 at the compact morula and blastocyst stages. Both heat shock and tunicamycin reduced the percent of embryos becoming a blastocyst but response was unaffected by PARM1 knockdown. Similarly, there was no effect of knockdown on steady-state amounts of ATF6, DDIT3 or EIF2AK3.
\end{abstract}

Conclusion: PARM1 participates in formation of TE and ICM cells in early embryonic development but there is no evidence for the role of PARM1 in the ER stress response.

Keywords: Embryo, Development, Blastocyst, PARM1, Gene expression, ER stress response

\section{Background}

During cleavage stages of development, the mammalian embryo experiences a series of morphological, molecular, physiological and metabolic processes that culminate in the transformation of a single-cell, totipotent zygote into a multicellular blastocyst composed of differentiated trophectoderm (TE) and a pluripotent inner cell mass (ICM) [1]. Initially, blastomeres are transcriptionally silent and the embryo depends upon on maternally-derived mRNA stored in the oocyte for new protein synthesis. Epigenetic

\footnotetext{
* Correspondence: Hansen@animal.ufl.edu

'Department of Animal Sciences, D.H. Barron Reproductive and Perinatal Biology Research Program and Genetics Institute, University of Florida, PO Box 110910, Gainesville, Florida 32611-0910, USA

Full list of author information is available at the end of the article
}

modifications and degradation of maternally-derived transcripts and proteins lead to activation of the embryonic genome at a species-specific cleavage stage [2]. In the bovine embryo, the first major round of genome activation is initiated at the $8-16$ cell stage [3].

One of the genes expressed coincident with embryonic genome activation in the cow is prostate androgenregulated mucin-like protein 1 (PARM1) [4] which encodes for a mucin-like type 1 transmembrane glycoprotein localized in the membrane of the endoplasmic reticulum (ER) [5, 6]. There was an association between a non-synonoymous single nucleotide polymoprhism (SNP) in the coding region of PARM1 with competence of cultured bovine embryos to develop to the blastocyst stage [7]; embryos sired by heterozygous bulls were

(c) The Author(s). 2019 Open Access This article is distributed under the terms of the Creative Commons Attribution 4.0 International License (http://creativecommons.org/licenses/by/4.0/), which permits unrestricted use, distribution, and 
more likely to become a blastocyst than embryos sired by bulls homozygous for either SNP. Such a result is indicative that PARM1 may play an important role in the preimplantation embryo.

There are at least two potential mechanisms by which PARM1 could affect development of the embryo to the blastocyst stage. The first is by regulation of cell differentiation because PARM1 can promote differentiation of cardiomyocytes [8] and adipocytes [9]. Actions on cardiomyocytes involve upregulation of expression of BMP2 and BMP4 [8]. Both of these bone morphogenetic proteins can regulate expression of transcription factor genes involved in differentiation [10]. Moreover, BMP4 promotes formation of trophoblastic cell lines from bovine blastocysts [11]. PARM1 could also improve embryonic development to the blastocyst stage by blocking ER stress induced apoptosis. Treatment of cardiomyocytes with silencing RNA targeting PARM1 inhibited expression of EITF2, AK3 and ATF6 (participants in the unfolded protein response during ER stress) and increased apoptosis activated by ER stress inducers [5]. In addition, inhibition of ER stress improved the proportion of mouse and cattle embryos developing to the blastocyst stage [12,13].

The objective of the present series of experiments was to determine whether PARM1 plays an important role in development and differentiation of the blastocyst in the bovine preimplantation embryo. Experiments were conducted in vitro to test whether reducing transcript abundance for PARM1 would affect the competence of the bovine embryo to develop to the blastocyst stage, alter the allocation of blastomeres in the blastocyst into TE and ICM lineages, change expression of genes important for embryonic development and alter embryo stress responses. Two types of stresses were evaluated. These were heat shock, which can reduce development to the blastocyst stage $[14,15]$ and which involves the ER stress response [16-18], and the glycosylation inhibitor tunicamycin, an ER stress inducer [19]. We also evaluated whether reducing transcript abundance for PARM1 would alter expression of three genes involved in the ER stress response, namely ATF6, DDIT3 and EIF2AK3. ATF6 and EIF2AK3 are ER sensory proteins which are kept inactivated by binding with ER-resident chaperones such as GRP78 and GRP94 [20]. Upon accumulation of misfolded proteins resulting from stress factors in the ER, the chaperones are occupied by the misfolded proteins, which results in the release and activation of the ER stress sensors, and subsequent activation of downstream signaling proteins such as CHOP. The DDIT3 encoded protein, CHOP, acts as distal effector of ER stress response by mediating apoptotic signals [20].

\section{Results}

Embryo development and differentiation (experiment 1 and 2)

The effectiveness of anti-PARM1 GapmeR for reducing abundance of PARM1 in morula and blastocyst stage embryos was confirmed using qPCR (Fig. 1). Treatment with anti-PARM1 GapmeR tended to decrease $(P=0.08)$ the percent of presumptive zygotes that cleaved at day 3.5 after fertilization (Fig. 2 top panel) but had no effect on the percent of either presumptive zygotes or cleaved embryos developing to the blastocyst stage (Fig. 2 middle panel and Fig. 2 bottom panel). Knockdown of PARM1 did not affect total number cells in blastocysts (Fig. 3 top panel) but decreased $(P=0.04)$ the number of trophectoderm cells (Fig. 3 middle panel) and tended to increase $(P=0.09)$ the number of ICM cells (Fig. 3 top panel).

\section{Transcript abundance for genes related to early} embryonic development (experiments 1 and 2)

Effects of reducing transcript abundance of PARM1 on gene expression was evaluated by determining

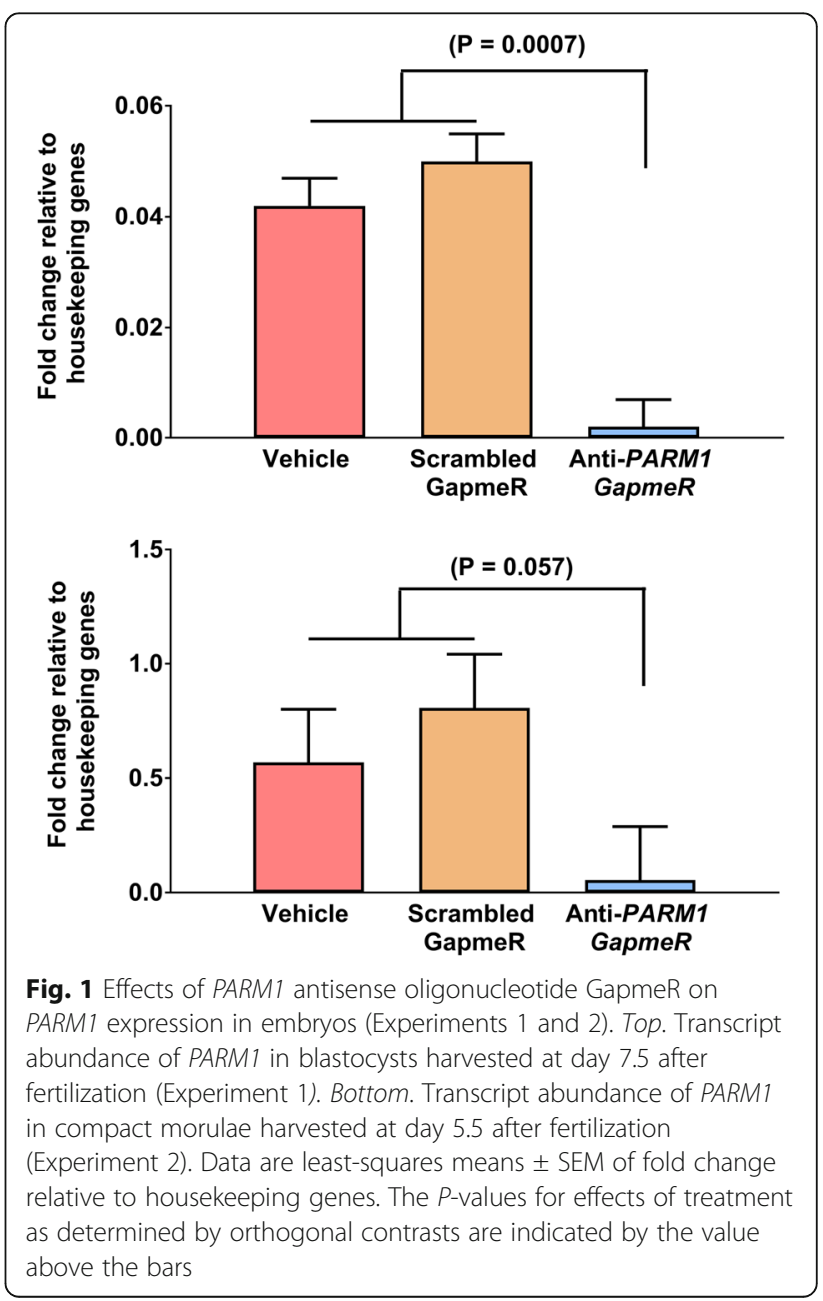




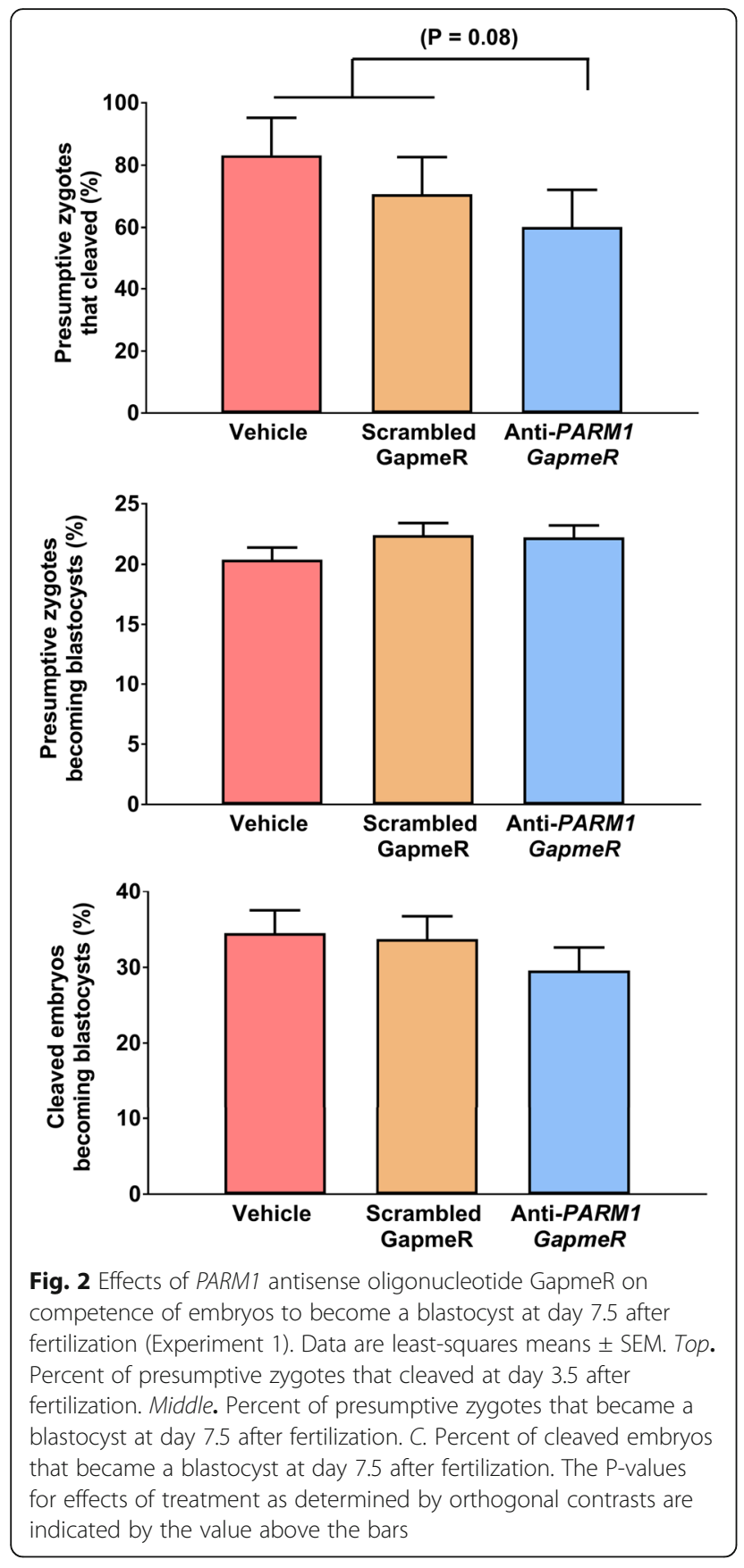

steady-state amounts of 90 genes selected for their role in embryonic development including those identified as markers of epiblast, TE or hypoblast, cell signaling pathways, genes involved in epigenetic modification and genes involved in tight junctions and, cell polarity. Gene expression was evaluated at morula (Experiment 2) and blastocyst stages (Experiment 1).

Least-squares means of fold change relative to housekeeping for all genes analyzed are shown in Additional file 1.

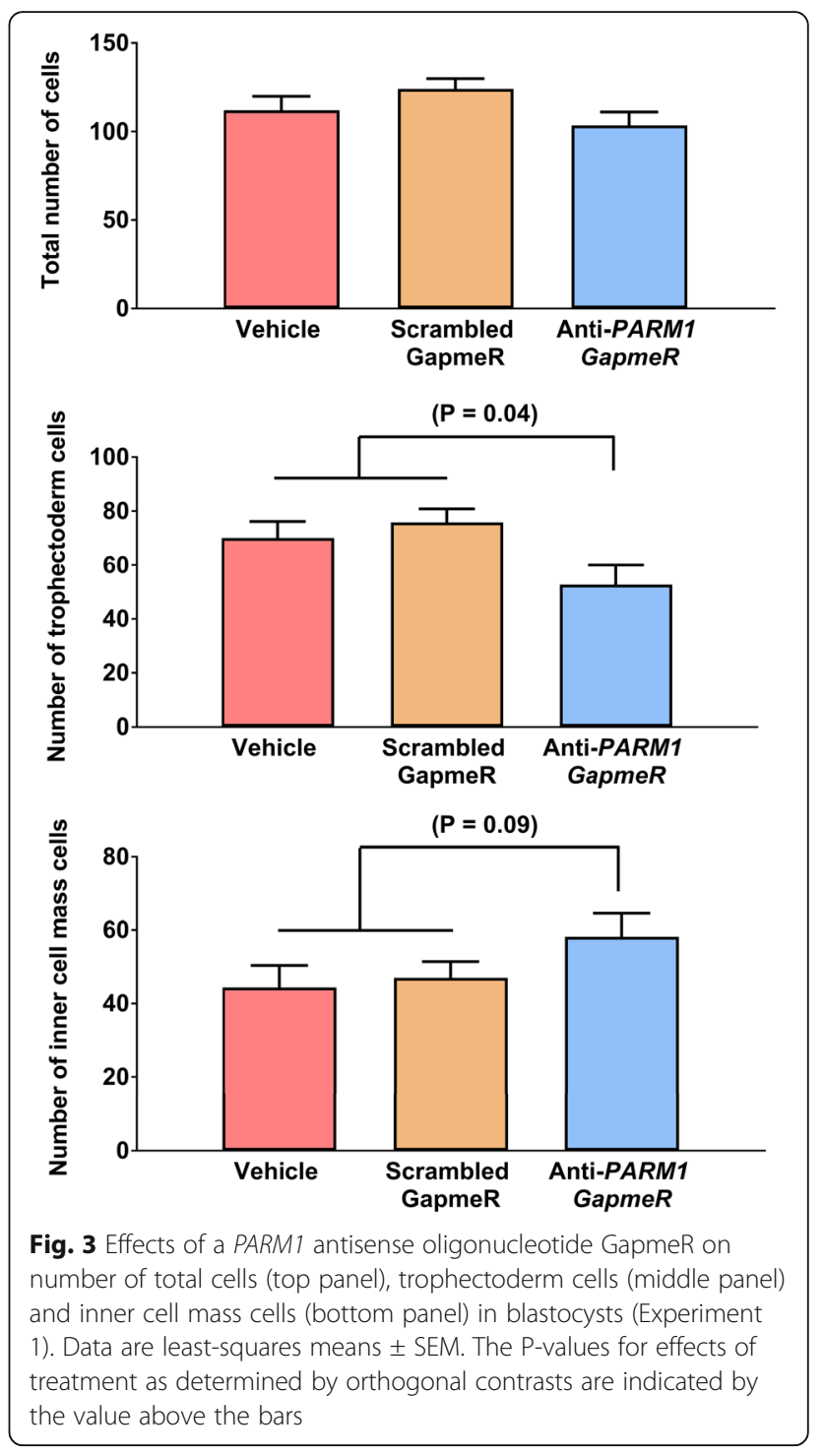

At the morula stage (Day 5.5), treatment of embryos with anti-PARM1 GapmeR increased expression of DAB2 $(P=$ $0.02)$, INADL $(P=0.04)$, and STAT3 $(P=0.05)$ and decreased $(P=0.03)$ amounts of mRNA for CCR2 (Fig. 4). At the blastocyst stage, treatment of embryos with antiPARM1 GapmeR increased expression of PECAM1 ( $\mathrm{P}=$ 0.05), TEAD4 $(\mathrm{P}=0.05)$, and decreased expression of CCR7 $(\mathrm{P}=0.03)$ (Fig. 5).

\section{Effect of knockdown of PARM1 on development of embryos after heat shock (experiment 3 )}

Heat shock treatment decreased $(\mathrm{P}=0.02)$ the percent of cleaved embryos that became a blastocyst at Day 7.5 but there was no effect of anti-PARM1 GapmeR or the interaction between anti-PARM1 GapmeR and heat shock (Fig. 6). 


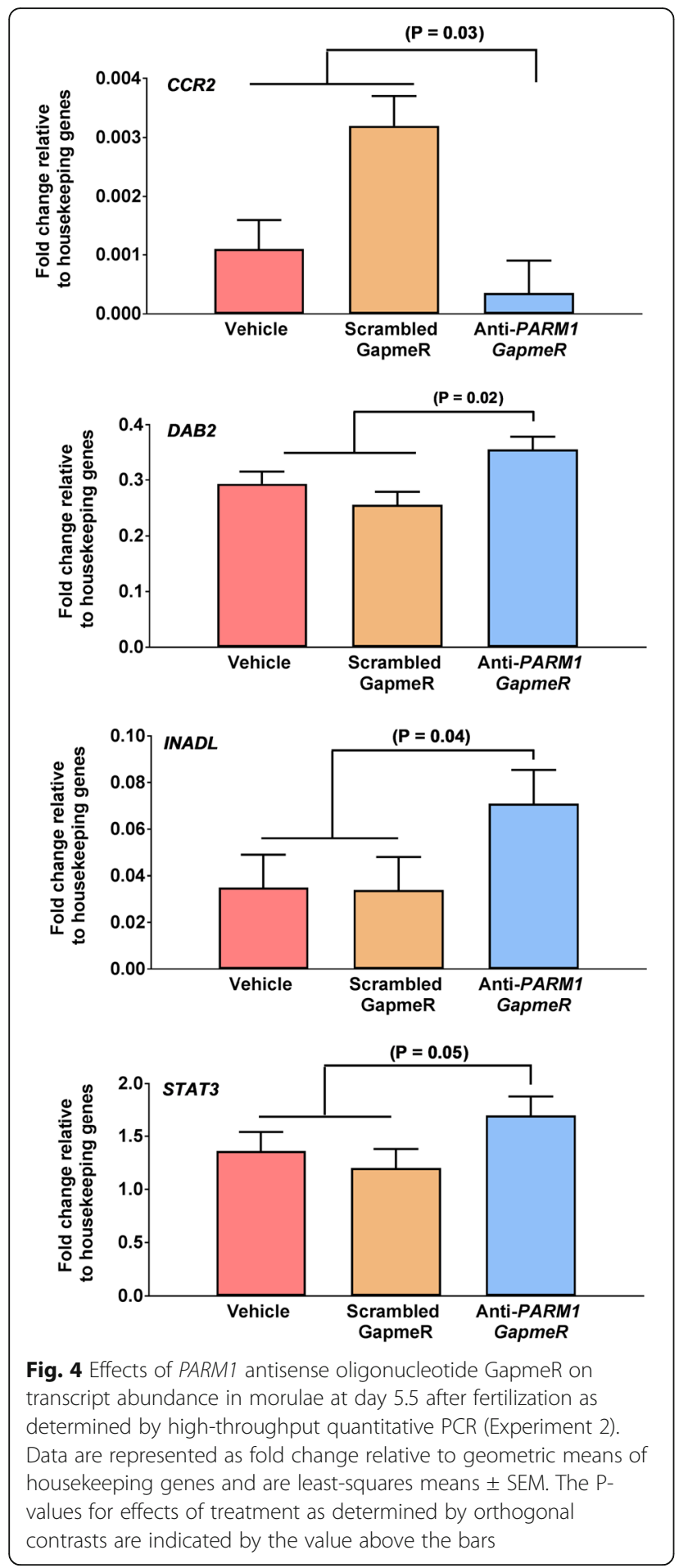

Effect of knockdown of PARM1 on development of embryos after tunicamycin treatment (experiment 4)

Tunicamycin decreased $(P=0.0001)$ the percent of presumptive zygotes that became a blastocyst at day 7.5 but there was no effect of anti-PARM1 GapmeR or the interaction between anti-PARM1 GapmeR and tunicamycin (Fig. 7).
Expression of genes involved in ER stress (experiments 5 and 6)

Treatment with anti-PARM1 GapmeR had no effect on steady-stage amounts of mRNA for ATF6, DDIT3 or $E I F 2 A K 3$ at either the compact morula or blastocyst stages of development (Fig. 8).

\section{Discussion}

Results reported here show that PARM1 is not required for development of the embryo to the blastocyst stage, does not play a role in determining whether an embryo can develop to the blastocyst stage after two treatments that can induce the ER stress response, heat shock [16-18] or tunicamycin exposure [19], and is not determinative for expression of key genes involved in the ER stress response. Nonetheless, PARM1 does play a role in the process of differentiation of the embryo into TE and ICM cells at the blastocyst stage. This is so because reducing PARM1 transcript abundance decreased the number of TE cells and tended to increase the number of ICM cells.

PARM1 is a pro-proliferative and anti-apoptotic glycoprotein $[6,21]$ and it is possible that PARM1 is involved in embryonic differentiation by promoting TE cell proliferation or reducing apoptosis of TE cells. If so, knockdown of PARM1 could result in lower TE cell number because of reduced proliferation or increased apoptosis. However, such a putative mechanism does not explain why knockdown of PARM1 also increased ICM cell number. A more likely explanation for the change in numbers of TE and ICM cells caused by PARM1 knockdown is that PARM1 is involved in allocation of blastomeres towards the TE or ICM lineages.

Examination of the effects of PARM1 knockdown on gene expression in embryos at the compact morula or blastocyst stage did not provide a clear picture of the mechanism by which PARM1 could favor allocation of blastomeres to TE rather than ICM. Most genes were not affected by treatment and many of the genes significantly affected were either very lowly expressed (CCR2 for compact morulae and CCR7 for blastocysts) or the magnitude of the effect was small. Three genes implicated in differentiation of the bovine blastocyst were not affected by anti-PARM1 GapmeR (see summary of results in Additional file 1). These were CDX2 [22-24] and YAP1 [25], important for TE formation, and POU5F1 [26] required for epiblast formation. There was also no effect of PARM1 knockdown on expression of $B M P 4$ even though overexpression of PARM1 in cardiomyocytes causes upregulation of $B M P 2$ and $B M P 4$ expression [8]. Expression of another gene important for TE differentiation in cattle, TEAD4 [24, 25, 27], was slightly increased in blastocysts produced in the presence of anti-PARM1 GapmeR. TEAD4 is required for expression of CDX2 [24] so an increase in TEAD4 


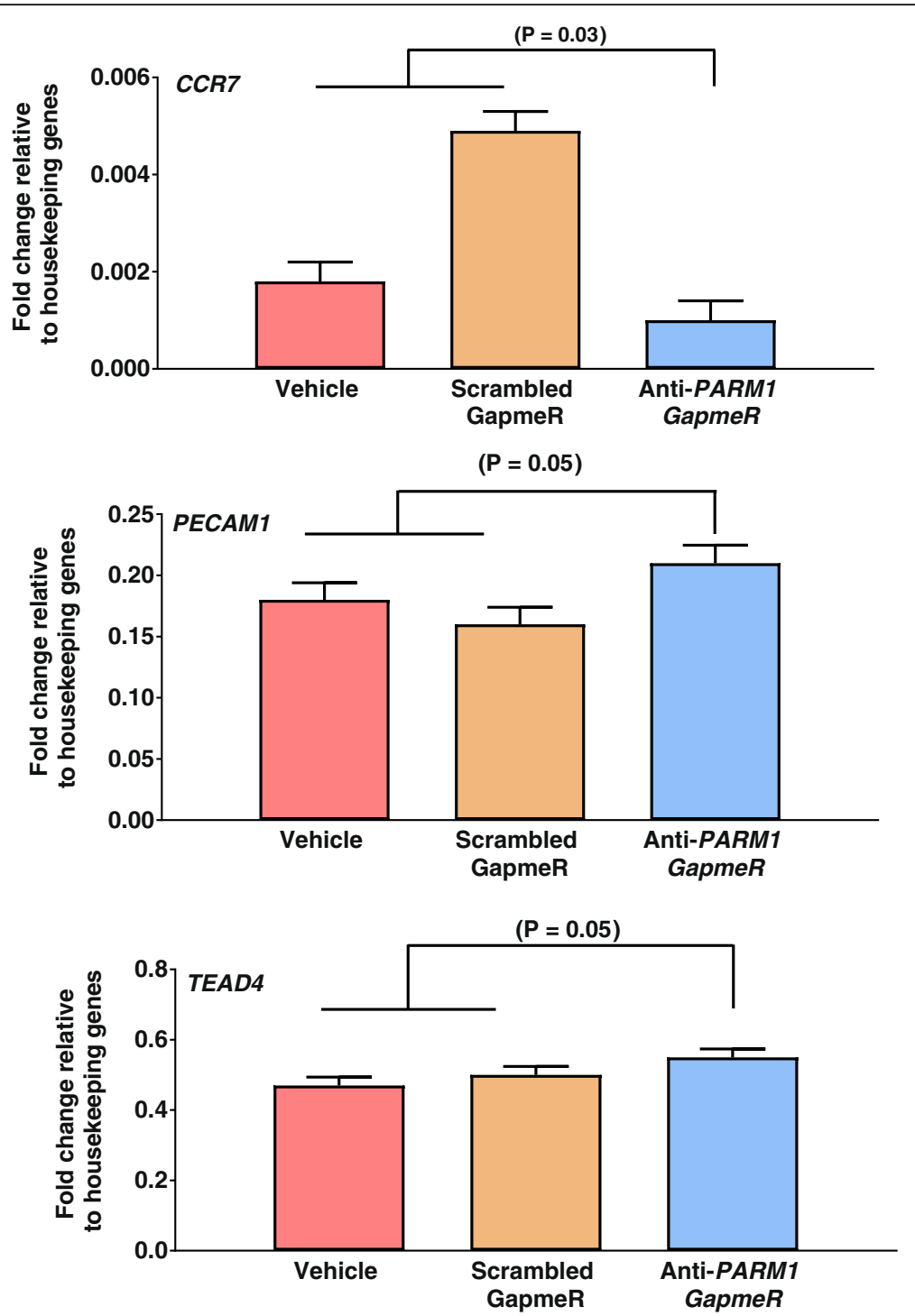

Fig. 5 Effects of PARM1 antisense oligonucleotide GapmeR on transcript abundance in blastocysts at day 7.5 after fertilization as determined by high-throughput quantitative PCR (Experiment 1). Data are represented as fold change relative to geometric means of housekeeping genes and are least-squares means \pm SEM. The P-values for effects of treatment as determined by orthogonal contrasts are indicated by the value above the bars

caused by the PARM1 knockdown is inconsistent with the idea that PARM1 is affecting TE cell numbers by regulation of TEAD4 expression.

Two genes whose expression was increased by PARM1, namely INADL at the compact morula stage and PECAM1 at the blastocyst stage, are involved in junctional complexes between cells. INADL encodes for a protein involved in tight junction formation [28] which is exclusive to TE cells and is essential for blastocoele formation in the mouse [29]. PECAM1 encodes for a transmembrane cell-adhesion protein involved in formation of adherens junctions [30]. PARM1 is a mucin present not only in the ER but also in the plasma membrane [31]. Perhaps PARM1 participates in cell-cell contact and reduction in amounts of PARM1 upon GapmeR treatment results in upregulation of these two genes involved in formation of junctional complexes. PARM1 knockdown also increased expression of $D A B 2$ in compact morulae. $D A B 2$ encodes a protein important for endocytosis [32] and PARM1 can be localized to early endosomes [31]. It has been proposed that endocytosis is important for cell polarization and tight junction formation in the mouse embryo [33] and perhaps actions of PARM1 to promote TE differentiation involve actions on endosome formation.

The knockdown of PARM1 caused increased expression of STAT3 at the compact-morula stage. In the bovine embryo, inhibition of STAT3 causes reduced ICM 


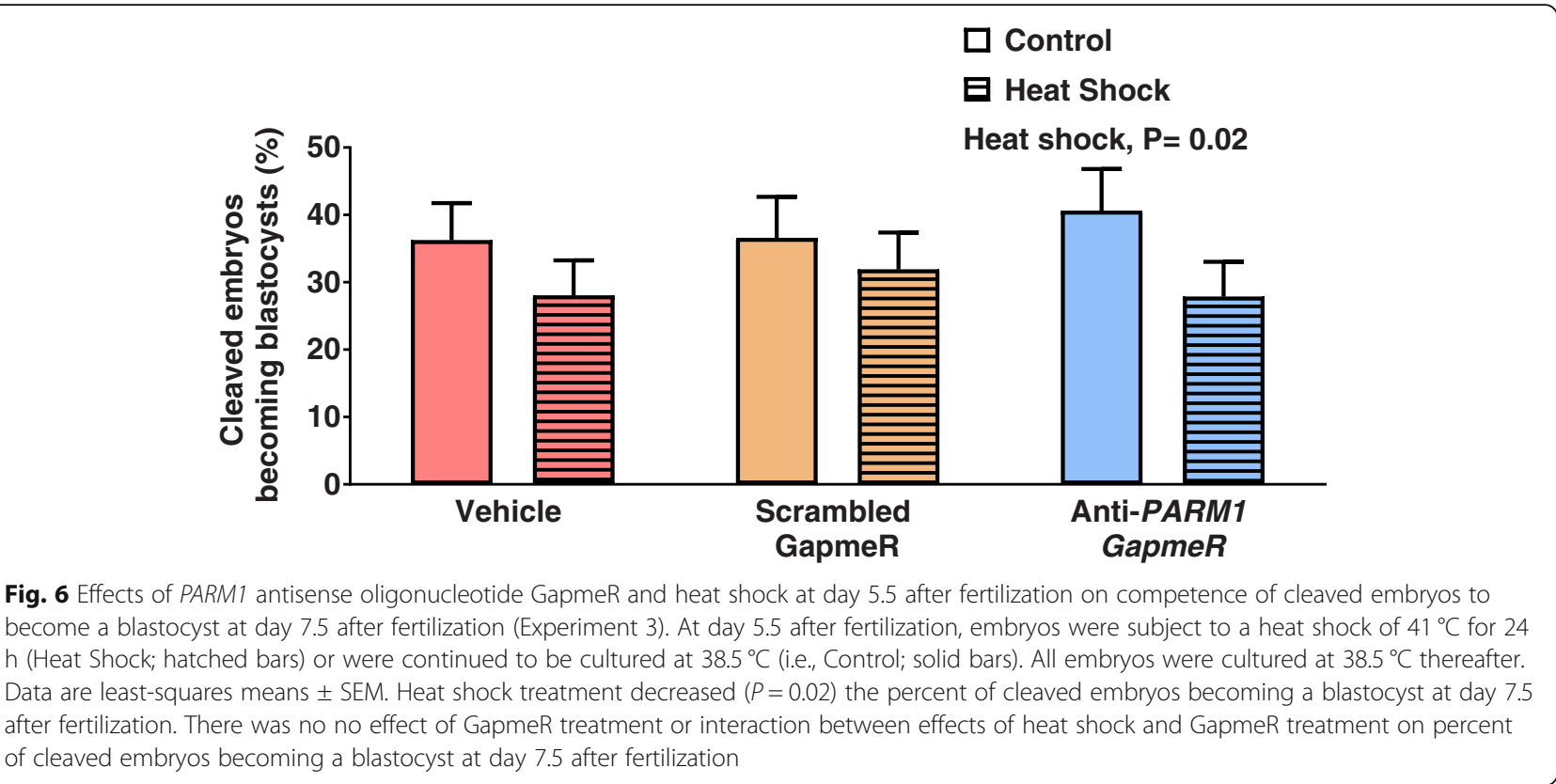

cell numbers and expression of NANOG [34] so the increase in expression of STAT3 caused by PARM1 knockdown could conceivably contribute to the increased numbers of ICM cells in blastocysts cultured with anti-PARM1 GapmeR. STAT3 participates in ICM maintenance in the mouse by upregulating pluripotency genes POU5F1 and NANOG [35].

Implications of a change in the relative numbers of $\mathrm{TE}$ and ICM cells in the blastocyst for subsequent competence to establish and maintain pregnancy are not known. The ratio of number of TE cells to number of ICM cells can be affected by culture conditions for in vitro produced embryos [36]. Loss of the embryonic disk at day $14-15$ is a frequent occurrence for embryos produced in vitro $[37,38]$. In vitro, morulae that were classified as poor based on morphological criteria had fewer ICM cells when they became hatched blastocysts [39]. Perhaps, overactivation of PARM1 expression for the embryo produced in vitro can affect the ratio of TE: ICM .

PARM1 is also present in the ER where it plays a role in the ER stress response [5]. There is no evidence, however, that PARM1 is involved in modulating the ER stress response in the bovine embryo. Knockdown of PARM1 did not make embryos more sensitive to the anti-developmental effects of heat shock or tunicamycin. Heat shock can activate the ER stress response in cultured cells $[16,17]$ and survival of cardiomyocytes to

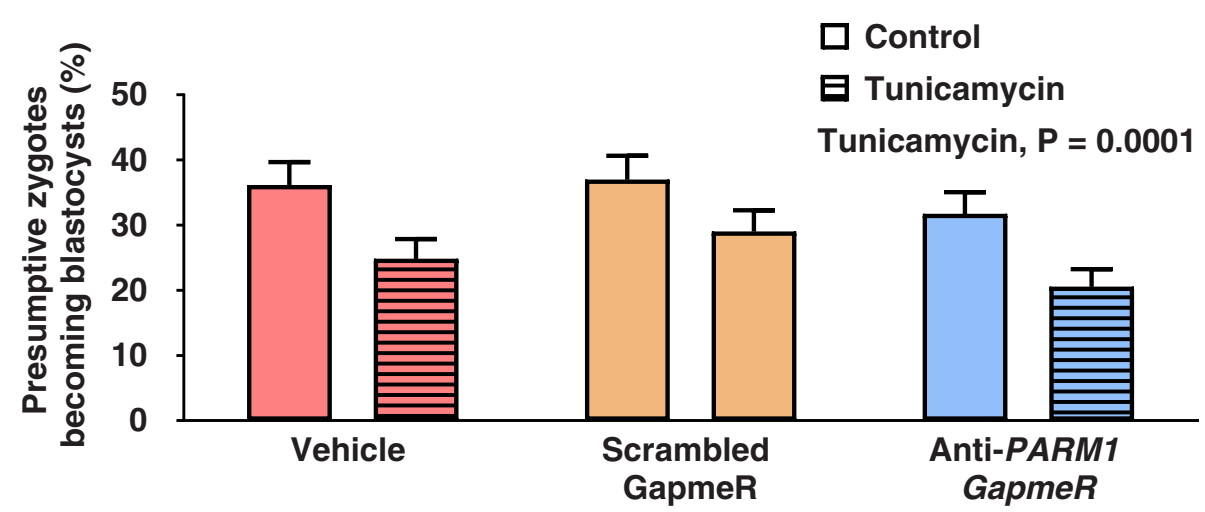

Fig. 7 Effects of PARM1 antisense oligonucleotide GapmeR and tunicamycin at day 5.5 after fertilization on competence of embryos to become a blastocyst at day 7.5 after fertilization (Experiment 4). Data are least-squares means \pm SEM. At day 5.5 after fertilization, $2.5 \mu \mathrm{L}$ of medium in the culture drop was replaced with $2.5 \mu \mathrm{L}$ SOF-BE2 containing vehicle (Control; solid bars) or tunicamycin $(0.5 \mu \mathrm{g} / \mathrm{mL}$ tunicamicyn so that the final concentration would be $0.05 \mu \mathrm{g} / \mathrm{mL}$; hatched bars). Treatment with tunicamycin decreased $(P=0.0001)$ the percent of presumptive zygotes becoming a blastocyst at day 7.5 after fertilization. There was no effect of GapmeR treatment or interaction between effects of tunicamycin treatment and GapmeR treatment on blastocyst development 

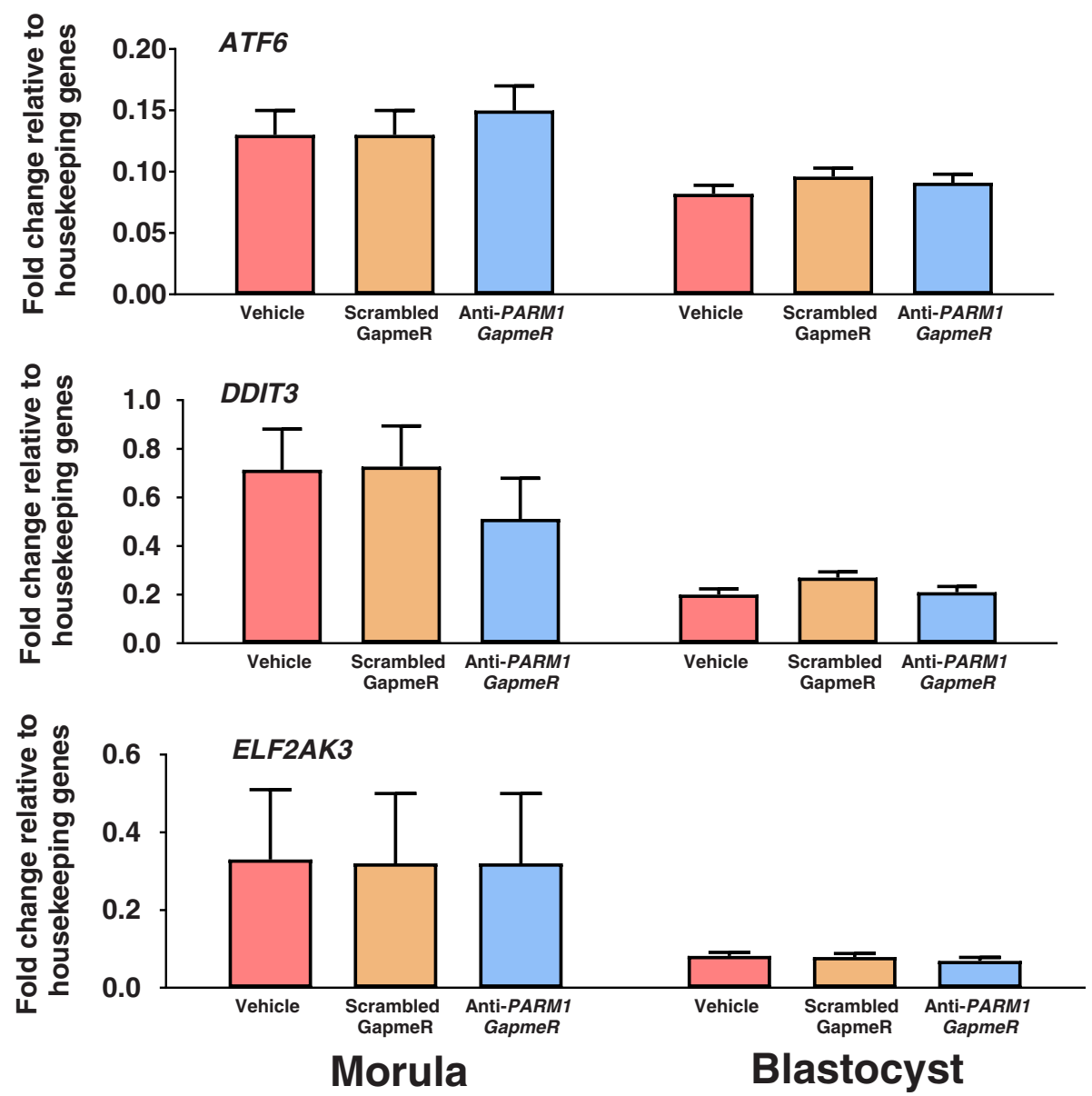

Fig. 8 Effects of PARM1 antisense oligonucleotide GapmeR on transcript abundance for selected genes involved in endoplasmic reticulum stress response in morulae (Experiment 5) and blastocysts (Experiment 6). Data are least-squares means \pm SEM. There was no treatment effect on gene expression of ATF6, DDIT3 and ELF2AK3 for morula-stage embryos collected at day 5.5 after fertilization and for blastocyst-stage embryos collected at day 7.5 after fertilization

this insult was enhanced when the ER stress response was attenuated [18]. Lack of effect of PARM1 knockdown on embryonic response to heat shock is indicative that either PARM1 is not involved in the ER stress response in the bovine embryo or the ER stress response was not activated by heat shock. To verify that PARM1 is not involved in ER stress response during early embryonic development embryos were treated with tunicamycin at day 5.5 after fertilization. As reported previously [40], tunicamycin induces ER stress response by blocking $\mathrm{N}$-glycosylation of proteins and can impair compaction and blastocyst formation. In the present experiment, tunicamycin had a large negative effect on competence of the embryo to become a blastocyst but this effect was not modified by anti-PARM1 GapmeR treatment. This result is also inconsistent with a role for PARM1 in the ER stress response. Further evidence against the involvement of PARM1 in the ER stress response in the bovine embryo was the observation that knockdown of PARM1 had no effect in the expression of three genes involved in the ER stress response, ATF6, DDIT3, and EIF2AK3.

The fact that treatment with anti-PARM1 GapmeR did not affect blastocyst formation implies that the SNP in PARM1 that was earlier associated with blastocyst development [7] is not a causative mutation. This SNP is a $\mathrm{G} \rightarrow \mathrm{C}$ missense mutation that induces an amino acid change from glycine to alanine at position 232. One possibility is that the SNP is in linkage disequilibrium with the actual causative mutation. The discovery of the relationship between the PARM1 SNP and embryonic development [7] was based on the effect of PARM1 genotype of the sire used to produce embryos and subsequent percent of embryos that became blastocysts in culture. It is also possible, therefore, that the SNP affects sperm function. Recent results also failed to find a relationship between the PARM1 SNP and fertility in lactating dairy cows [41]. 


\section{Conclusion}

Present results indicate that PARM1 should be considered as part of the gene network involved in TE and ICM formation. As such, it is the first gene encoding for an ER protein found to be implicated in cellular differentiation of the blastocyst. Future studies should be done to investigate the precise location of PARM1 in embryonic cells and the proteins that interact with PARM1 to affect differentiation of the morula into TE and ICM.

\section{Methods}

\section{In vitro production of bovine embryos}

All experiments were performed with embryos produced in vitro using a previously-described protocol [4, 25, 42, 43]. Briefly, ovaries from Bos taurus or admixtures of $B$. taurus and $B$. indicus cattle were used to harvest cumulus-oocyte complexes (COC). Harvest was accomplished by by slicing visible ovarian follicles $(2-8 \mathrm{~mm}$ in diameter) and rinsing the sliced ovary in oocyte washing medium (MOFA Global, Verona, WI, USA). The COC were matured for $22 \mathrm{~h}$ at $38.5^{\circ} \mathrm{C}$ in a humidified atmosphere of $5 \%(\mathrm{v} / \mathrm{v}) \mathrm{CO}_{2}$ in groups of 10 in $50 \mu \mathrm{L}$ oilcovered drops of a commercial oocyte maturation medium (BO-IVM Biosciences, Cornwall, United Kingdom). Fertilization of matured oocytes was performed by placing up to $300 \mathrm{COC}$ with frozen-thawed, Isolate ${ }^{\bullet}$ (Irvine Scientific, Santa Ana, CA, USA)-purified sperm $\left(1 \times 10^{6} / \mathrm{ml}\right)$ pooled from three bulls of various breeds. A replicate was considered all oocytes collected on one day and different pools of sperm were used for different replicates. Fertilization took place in n-vitro fertilizationTyrode's albumin lactate pyruvate (IVF-TALP) that contained $20 \mu \mathrm{M}$ penicillamine, $10 \mu \mathrm{M}$ hypotaurine and $0.007 \mu \mathrm{M}$ epinephrine. Fertilization proceeded for $12-14$ $\mathrm{h}$ at $38.5^{\circ} \mathrm{C}$ in a humidified gas atmosphere of $5 \%(\mathrm{v} / \mathrm{v})$ $\mathrm{CO}_{2}$, and with the balance nitrogen. Cumulus cells were removed from presumptive zygotes after fertilization by vortexing with $1000 \mathrm{U} / \mathrm{ml}$ hyaluronidase in $\sim 0.5 \mathrm{ml}$ HEPES-TALP. After washing 3x in HEPES-TALP, groups of 15 presumptive zygotes were cultured at $38.5^{\circ} \mathrm{C}$ in a humidified gas atmosphere of $5 \%(\mathrm{v} / \mathrm{v}) \mathrm{CO}_{2}, 5 \%(\mathrm{v} / \mathrm{v}) \mathrm{O}_{2}$ with the balance nitrogen in $25 \mu \mathrm{l}$ oil-covered drops of synthetic oviductal fluid-bovine embryo 2 (SOF-BE2).

\section{Knockdown of PARM1}

Knockdown was performed using GapmeR LNA $^{\mathrm{TM}}$ antisense oligonucleotides from Exiqon (Woburn, MA, USA) using procedures employed previously to knockdown mRNA for WBP1 [4], YAP1 [25] and AMOT [25]. Two GapmeR were designed by Exiqon: one to target the PARM1 sequence and a scrambled version of the same sequence used as a negative control. The sequence that targeted PARM1 (termed anti-PARM1) was 5'GTGAAGTAGGTGTGAG-3'. The sequence for the scrambled negative control was $5^{\prime}$-TTGGATGGTGGAGAGA-3'. Sequences were evaluated to ensure that they do not hybridize to other genes. Presumptive zygotes (i.e., oocytes exposed to sperm and placed in embryo culture) were randomly treated at $22 \mathrm{~h}$ post insemination with either $5 \mu \mathrm{M}$ anti-PARM1 GapmeR, $5 \mu \mathrm{M}$ scrambled GapmeR, or vehicle (RNA free water) added to SOF-BE2 culture medium. A single administration of treatment was applied and embryos were cultured with the relevant treatment for the entire duration of culture without addition of additional GapmeR.

\section{Determination of the number of ICM and TE cells by immunofluorescence}

Cells that were TE were distinguished from cells in the ICM based on nuclear labeling for CDX2 using procedures similar to those previously published [4, 25, 44, 45]. The primary antibody was ready-to-use mouse monoclonal antibody against CDX2 (BioGenex, Fremont, CA, USA; reference AM392-5 M, lot AM3920917) For randomly-selected embryos, mouse $1 \mathrm{gG}(1 \mu \mathrm{g} / \mathrm{mL})$ was used as a negative control. The second antibody was $1 \mu \mathrm{g} / \mathrm{ml}$ fluorescein isothiocyanate labeled goat anti-mouse IgG. Nuclei were labeled with $1 \mu \mathrm{g} / \mathrm{ml}$ Hoechst 33342. Fluorescence was observed with a Zeiss Axioplan 2 epifluorescence microscope (Zeiss, Gottingen, Germany) with a $40 \mathrm{x}$ objective and using Zeiss filter sets 02 (blue) and 03 (green). Digital images were acquired using AxioVision software (Zeiss) and a high-resolution black and white Zeiss AxioCam MRm digital camera. Total cell number was determined by counting nuclei labeled with Hoescht 33,342, number of TE cells was determined by counting nuclei positive for CDX2 and number of ICM cells was determined by subtracting number of TE cells from total cell number.

\section{RNA isolation}

Pools of embryos were treated with $0.1 \%(\mathrm{w} / \mathrm{v})$ protease from Streptococcus griseus in DPBS containing 1\% $(\mathrm{w} / \mathrm{v})$ polyvinylpyrrolidone to remove the zona pellucida, washed three times in $50 \mu$ d droplets of DPBS containing 1\% PVP, placed in $5 \mathrm{~mL}$ DEPC-treated DPBS-1\% PVP in microcentrifuge tubes, snap-frozen in liquid nitrogen and stored at $-80^{\circ} \mathrm{C}$ until further analysis. For RNA extraction, the PicoPure RNA isolation kit (Applied Biosystems, Carlsbad, CA, USA) was used following the manufacturer's instructions by loading onto MiraCol purification column and eluting with buffer. Isolated RNA $(10 \mu \mathrm{l})$ was treated with $1 \mu \mathrm{L}(2 \mathrm{U})$ of DNaseI (New England Biolabs, Ipswich, MA, USA) for removal of DNA contamination prior to reverse transcription. 


\section{Analysis of expression of individual genes using quantitative PCR}

Reverse transcription was performed with the High Capacity cDNA Reverse Transcription Kit (Applied Biosystems). A negative control without reverse transcriptase was included for each stamples. The PCR was carried out using a CFX96 Real-Time PCR detection System (Bio-Rad, Hercules, CA, USA) and the SsoFast EvaGreen Supermix ${ }^{\oplus}$ with Low ROX (Bio-Rad) as described elsewhere [4]. Genes whose expression was determerined were ATF6, DIT3, ELF2AK3, and PARM1. Primer sequences are detailed in Table 1 . Validation for each set of primers included a standard curve with a slope between -3 and -3.3 , verification that melting curves incdicated a single, specific product, confirmation of amplicon size by agarose gel electrophoresis and Sanger sequencing of the PCR product to condirm sequence identify.

\section{Analysis of expression of individual genes using high- throughput quantitative PCR}

The Fluidigm qPCR microfluidic device Biomark HD system was used to analyze the effect of PARM1 knockdown on 96 selected genes using primer pairs and protocol published earlier [25]. Primers were designed by Fluidigm Delta Gene assays (Fluidigm Co., San Francisco, CA, USA) and optimized by Miami Center for AIDS Research at the University of Miami Miller School of Medicine. One primer pair, for $K L F 2$, was not validated and results for this gene were not used for further analysis. Amongst the 95 remaining genes were 5 housekeeping genes, 9 epiblast potential specific markers, 12 markers of trophoblast in one or more species, 9 hypoblast markers, 16 chemokine signaling pathway genes, 9 Hippo signaling pathway genes, 13 epigenetic modification gene markers, 14 tight junctions, cell polarity and axon guidance, and another 9 genes of interest.

RNA was extracted using the Qiagen RNeasy Micro Kit (Qiagen) following the manufacturer's instructions. The RNA isolation procedure included DNase treatment. Elution of RNA was performed in a volume of $20 \mu \mathrm{L}(7+7 \mu \mathrm{L})$. The High Capacity cDNA Reverse Transcription Kit (Applied Biosystems) was used for cDNA synthesis following manufacturer's instructions.
The cDNA was stored at $-20^{\circ} \mathrm{C}$ until further use. The Cells Direct Kit (Life Technologies) was used for preamplification to perform 18 cDNA synthesis cycles, followed by exonuclease I treatment and loading into the microfluidic chip (1:2 dilution). The 96.96 dynamic array Fluidigm integrated fluidic circuit was used to perform PCR. The limit of detection was set as a $\mathrm{Ct}$ value greater than 27 cycle. The delta $\mathrm{Ct}(\mathrm{dCt})$ values were calculated by the difference between the $\mathrm{Ct}$ and the geometric mean of the $\mathrm{Ct}$ values for the five housekeeping genes (ACTB, GAPDH, H2AFZ, HPRT1 and SDHA) was calculated and used to obtain the delta $\mathrm{Ct}(\mathrm{dCt})$ values of the other genes. The fold change $\left(2^{-\mathrm{dCt}}\right)$ was analyzed statistically.

\section{Experiments}

For Experiment 1, it was tested whether knockdown of PARM1 would compromise competence of embryos to develop to the blastocyst stage, alter TE and ICM differentiation and affect transcript abundance in blastocysts. Embryos were produced in vitro as indicated above. The experiment was performed in 4 replicates. For each replicate, embryos were treated at $22 \mathrm{hpi}$ with vehicle (a negative control containing the same volume of diluent used to prepare the GapmeRs), $5 \mu \mathrm{M}$ scrambled GapmeR (another negative control to account for nonspecific effects of GapmeR) or $5 \mu \mathrm{M}$ anti-PARM1 GapmeR added to the culture medium. For each replicate, the percent of presumptive zygotes that cleaved was evaluated at day 3.5 after fertilization and percent of presumptive zygotes and cleaved embryos that became blastocysts were evaluated at day 7.5 after fertilization (Fig. 2). Blastocysts were collected at day 7.5 to either measure gene expression (Figs. 1 and 4) or blastocyst cell number (Fig. 3). Gene expression for PARM1 was performed by quantitative PCR in 4 pools per treatment of 12-20 blastocysts each (Fig. 1). In addition, expression of 96 genes by high-throughput PCR was determined for 4 pools of 12-15 blastocysts each (Fig. 5). A similar number of embryos were pooled for each treatment in each replicate. The total number of blastocysts evaluated for number of ICM and TE cells by immunofluorescence was 62 (produced in 3 replicates).

Table 1 Nucleotide sequence of the forward and reverse primers used for quantitative PCR

\begin{tabular}{llll}
\hline Gene & Accession number & Forward primer & Reverse primer \\
\hline ATF6 & BC120388 & TCATAGGCACGAAGTGGAAAG & CCAGAGCACCCTGAAGAATAC \\
DDIT3 & NM_001078163 & CTCTCTGGCTTGGCTTACTG & GTTCTTCCTTGGTCTTCCTCTT \\
EIF2AK3 & NM_001098086.1 & GCTATCAAGAGAATCCGTCTCC & TCTCACAATTCCTGGGTGTTC \\
PARM1 & NM_001075771.2 & AGCTCTACTCTCACACCTACTT & GTGGTGGTCTCCATGTCTATC \\
GAPDH & NM_001034034 & TTCAACGGCACAGTCAAGG & ACATACTCAGCACCAGCATCAC \\
YWHAZ & BM446307 & GCATCCCACAGACTATTCC & GCAAAGACAATGACAGACCA \\
\hline
\end{tabular}


Experiment 2 was performed to test whether knockdown of PARM1 would affect transcript abundance in compact morulae. Embryos were produced and treated as described for Experiment 1 except that compact morulae were collected at day 5.5 after fertilization. Gene expression for PARM1 was performed by quantitative PCR for 4 pools per treatment of 17-20 compact morula each (Fig. 1) and expression of 96 genes was determined thought high-throughput PCR for 4 pools of 12-15 compact morulae each (Fig. 4). A similar number of embryos were pooled for each treatment in each replicate.

Experiment 3 was designed to test whether negative effects of heat shock on development of morulae to the blastocyst stage would be enhanced in embryos in which transcript abundance of PARM1 was reduced by GapmeR treatment. Embryos were produced in vitro and cultured with GapmeR treatments (vehicle, $5 \mu \mathrm{M}$ scrambled GapmeR, or $5 \mu \mathrm{M}$ anti-PARM1 GapmeR). At day 5.5 after fertilization, embryos from each treatment were subjected to a heat shock of $41^{\circ} \mathrm{C}$ for $24 \mathrm{~h}$ or were continued to be cultured at $38.5^{\circ} \mathrm{C}$ (i.e., control). All embryos were cultured at $38.5^{\circ} \mathrm{C}$ thereafter. The endpoint was the percent of cleaved embryos that became blastocysts at day 7.5 after fertilization (Fig. 6). The number of replicates was 4 and there were an average of 310 presumptive zygotes per treatment.

The purpose of Experiment 4 was similar to that of Experiment 3 except that ER stress was induced with the glycosylation inhibitor tunicamycin [19]. Embryos were produced in vitro and cultured with GapmeR treatments (vehicle, $5 \mu \mathrm{M}$ scrambled GapmeR, or $5 \mu \mathrm{M}$ anti-PARM1 GapmeR). Some oocytes were collected locally and some oocytes were purchased from a commercial in vitro fertilization company (Vytelle, Hermiston, OR, USA). At day 5.5 after fertilization, embryos from each treatment group received treatment for tunicamycin by replacement of $2.5 \mu \mathrm{L}$ of medium in the culture drop with $2.5 \mu \mathrm{L}$ SOFBE2 containing the diluent vehicle for tunicamycin (control) or tunicamycin $(0.5 \mu \mathrm{g} / \mathrm{mL}$ tunicamicyn so that the final concentration would be $0.05 \mu \mathrm{g} / \mathrm{mL}$ ) (Fig. 7). The number of replicates was 3 and there were an average of 200 presumptive zygotes per treatment.

Two experiments were performed to test whether knockdown of PARM1 would affect gene expression of three genes involved in ER stress response in compactmorula (Experiment 5) and blastocysts (Experiment 6) (Fig. 8). Embryos were produced in vitro and cultured with GapmeR treatments (vehicle, $5 \mu \mathrm{M}$ scrambled GapmeR, or $5 \mu \mathrm{M}$ anti-PARM1 GapmeR) as described above. Four pools of 15-20 compact morulae collected at day 5.5 after fertilization and 4 pools of 10-15 blastocysts collected at Day 7.5 after fertilization were used to measure mRNA for ATF6, DDIT3 and EIF2AK3 by PCR.

\section{Statistical analysis}

The generalized linear mixed models procedure (Proc GLIMMIX) of SAS (SAS Institute Inc., Cary, NC, USA) was used to evaluate effects of treatment on the percent of presumptive zygotes that cleaved and the percent of presumptive zygotes or cleaved embryos that developed to the blastocyst stage. Each embryo was considered as an individual observation. Cleavage and development to the blastocyst stage were analyzed as binary variables $(0=$ did not occur; $1=$ occurred $)$. Treatments $($ GapmeR, temperature and tunicamicyn) were considered as fixed effects and replicate was considered a random effect. Orthogonal contrasts were used to partition treatment variance into individual comparisons as follows: AntiPARM1 GapmeR vs controls (scrambled GapmeR and vehicle) and scrambled GapmeR vs vehicle.

Treatment effects on other variables (cell number and gene expression calculated as fold-change relative to housekeeping genes) were determined by analysis of variance using the generalized linear models procedure (Proc GLM) of SAS. The model for cell number included the effect of treatment as a fixed effect. The model for gene expression included effect of treatment and replicate as fixed effects. Orthogonal contrasts were used as described above. In all cases, $P<0.05$ was considered significant and $P<0.10$ a statistical tendency.

\section{Additional file}

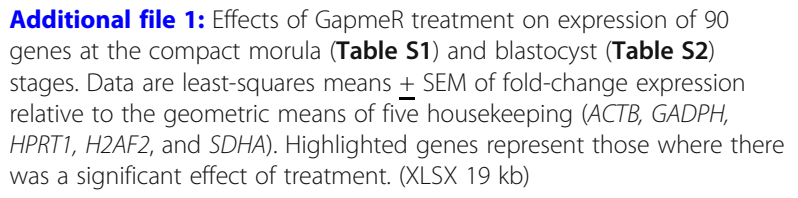

Additional file 1: Effects of GapmeR treatment on expression of 90 genes at the compact morula (Table S1) and blastocyst (Table S2) stages. Data are least-squares means + SEM of fold-change expression relative to the geometric means of five housekeeping (ACTB, GADPH, HPRT1, H2AF2, and SDHA). Highlighted genes represent those where there was a significant effect of treatment. (XLSX $19 \mathrm{~kb}$ )

\section{Abbreviations}

COC: Cumulus-oocyte complex; DPBS: Dulbecco's phosphate-buffered saline; ER: Endoplasmic reticulum; HEPES-TALP: HEPES -Tyrode's albumin lactate pyruvate (IVF-TALP); ICM: Inner cell mass; IVF-TALP: In-vitro fertilizationTyrode's albumin lactate pyruvate; PVP: Polyvinylpyrrolidone; SOFBE2: Synthetic oviduct fluid - bovine embryo 2; TE: Trophectoderm

\section{Acknowledgements}

The authors thank Florida Beef, Wauchula, Florida, for providing ovaries, and Eddie Cummings and James I. Moss, for technical assistance.

\section{Authors' contributions}

AZ performed experiments, analyzed data and wrote the first draft of the paper. VNP assisted in generation of scrambled and PARM1 target GapmeR. $\mathrm{PJH}$ oversaw the research, analyzed data and participated in writing the paper. All authors edited the manuscript and approved the final version.

\section{Funding}

Research was supported by Agriculture and Food Research Initiative Competitive Grant no. 2013-68004-20365 from the USDA National Institute of Food and Agriculture, Binational Research and Development Grant US4719-14 and funds from the L.E. "Red" Larson Endowment. AZ was supported by Coordenação de Aperfeiçoamento de Pessoal de Nível Superior (CAPES). 


\section{Availability of data and materials}

The datasets used and/or analysed during the current study are available from the corresponding author on reasonable request.

\section{Ethics approval and consent to participate}

Not applicable.

\section{Consent for publication}

Not applicable.

\section{Competing interests}

The authors declare that they have no competing interests.

\section{Author details}

'Department of Animal Sciences, D.H. Barron Reproductive and Perinatal Biology Research Program and Genetics Institute, University of Florida, PO Box 110910, Gainesville, Florida 32611-0910, USA. ${ }^{2}$ Present address: Department of Animal and Poultry Sciences, Virginia Tech, Blacksburg, VA 24061, USA.

Received: 28 February 2019 Accepted: 19 June 2019

Published online: 05 July 2019

\section{References}

1. Pfeffer PL. Building principles for constructing a mammalian blastocyst embryo. Biology (Basel). 2018;7:41. https://doi.org/10.3390/biology7030041.

2. Liu C, Ma Y, Shang Y, Huo R, Li W. Post-translational regulation of the maternal-to-zygotic transition. Cell Mol Life Sci. 2018;75:1707-22. https://doi.org/10.1007/s00018-018-2750-y.

3. Graf A, Krebs S, Zakhartchenko V, Schwalb B, Blum H, Wolf E. Fine mapping of genome activation in bovine embryos by RNA sequencing. Proc Natl Acad Sci U S A. 2014;111:4139-44. https://doi.org/10.1073/pnas.1321569111.

4. Ortega MS, Kurian JJ, McKenna R, Hansen PJ. Characteristics of candidate genes associated with embryonic development in the cow: evidence for a role for WBP1 in development to the blastocyst stage. PLoS One. 2017;12. https://doi.org/10.1371/journal.pone.0178041.

5. Isodono K, Takahashi T, Imoto H, Nakanishi N, Ogata T, Asada S, et al. PARM1 is an endoplasmic reticulum molecule involved in endoplasmic reticulum stress-induced apoptosis in rat cardiac myocytes. PLoS One. 2010;5:e9746. https://doi.org/10.1371/journal.pone.0009746.

6. Fladeby C, Gupta SN, Barois N, Lorenzo PI, Simpson JC, Saatcioglu F, et al. Human PARM1 is a novel mucin-like, androgen-regulated gene exhibiting proliferative effects in prostate cancer cells. Int J Cancer. 2008;122:1229-35. https://doi.org/10.1002/ijc.23185.

7. Cochran SD, Cole JB, Null DJ, Hansen PJ. Single nucleotide polymorphisms in candidate genes associated with fertilizing ability of sperm and subsequent embryonic development in cattle. Biol Reprod. 2013;89:69. https://doi.org/10.1095/biolreprod.113.111260.

8. Nakanishi N, Takahashi T, Ogata T, Adachi A, Imoto-Tsubakimoto H, Ueyama T, et al. PARM-1 promotes cardiomyogenic differentiation through regulating the BMP/Smad signaling pathway. Biochem Biophys Res Commun. 2012;428:500-5. https://doi.org/10.1016/J.BBRC.2012.10.078.

9. Song S-H, Hong Y-H, Sasaki S, Roh S-G, Katoh K. Prostatic androgen-repressed message-1 as a regulator of adipocyte differentiation in the mouse. Tohoku J Exp Med. 2009:219:311-7. https://doi.org/10.1620/tjem.219.311.

10. Wang RN, Green J, Wang Z, Deng Y, Qiao M, Peabody M, et al. Bone morphogenetic protein (BMP) signaling in development and human diseases. Genes Dis. 2014;1:87-105. https://doi.org/10.1016/J.GENDIS.2014.07.005.

11. Suzuki Y, Koshi K, Imai K, Takahashi T, Kizaki K, Hashizume K. Bone morphogenetic protein 4 accelerates the establishment of bovine trophoblastic cell lines. Reproduction. 2011;142:733-43. https://doi.org/10.1530/REP-11-0275.

12. Zhang JY, Diao YF, Kim HR, Jin D. II. Inhibition of endoplasmic reticulum stress improves mouse embryo development. PLoS One. 2012;7:e40433. https://doi.org/10.1371/journal.pone.0040433.

13. Song B-S, Yoon S-B, Kim J-S, Sim B-W, Kim Y-H, Cha J-J, et al. Induction of autophagy promotes preattachment development of bovine embryos by reducing endoplasmic reticulum stress1. Biol Reprod. 2012;87(8):1-11. https://doi.org/10.1095/biolreprod.111.097949.

14. Sakatani M, Kobayashi S-I, Takahashi M. Effects of heat shock on in vitro development and intracellular oxidative state of bovine preimplantation embryos. Mol Reprod Dev. 2004;67:77-82. https://doi.org/10.1002/mrd. 20014.

15. Krininger III CE, Stephens SH, Hansen PJ. Developmental changes in inhibitory effects of arsenic and heat shock on growth of pre-implantation bovine embryos. Mol Reprod Dev. 2002;63:335-40. https://doi.org/10.1002/ $\operatorname{mrd} .90017$.

16. Xu X, Gupta S, Hu W, McGrath BC, Cavener DR. Hyperthermia induces the ER stress pathway. PLoS One. 2011;6:e23740. https://doi.org/10.1371/journal. pone. 0023740 .

17. Bettaieb A, Averill-Bates DA. Thermotolerance induced at a mild temperature of $40^{\circ} \mathrm{C}$ alleviates heat shock-induced ER stress and apoptosis in HeLa cells. Biochim Biophys Acta. 2015;1853:52-62.

18. Yang Y, Li C, Xiang X, Dai Z, Chang J, Zhang M, et al. Ursolic acid prevents endoplasmic reticulum stress-mediated apoptosis induced by heat stress in mouse cardiac myocytes. J Mol Cell Cardiol. 2014;67:103-11.

19. Guha P, Kaptan E, Gade P, Kalvakolanu DV, Ahmed H. Tunicamycin induced endoplasmic reticulum stress promotes apoptosis of prostate cancer cells by activating mTORC1. Oncotarget. 2017;8:68191-207. https://doi.org/10. 18632/oncotarget.19277.

20. Lai E, Teodoro T, Volchuk A. Endoplasmic reticulum stress: signaling the unfolded protein response. Physiology. 2007;22:193-201.

21. Cornet AM, Hanon E, Reiter ER, Bruyninx M, Nguyen VH, Hennuy BR, et al. Prostatic androgen repressed message-1 (PARM-1) may play a role in prostatic cell immortalisation. Prostate. 2003;56:220-30. https://doi.org/10. 1002/pros.10254.

22. Berg DK, Smith CS, Pearton DJ, Wells DN, Broadhurst R, Donnison M, et al. Trophectoderm lineage determination in cattle. Dev Cell. 2011;20:244-55. https://doi.org/10.1016/J.DEVCEL.2011.01.003.

23. Goissis MD, Cibelli JB. Functional characterization of CDX2 during bovine preimplantation development in vitro. Mol Reprod Dev. 2014;81:962-70. https://doi.org/10.1002/mrd.22415.

24. Sakurai N, Takahashi K, Emura N, Fujii T, Hirayama H, Kageyama S, et al. The necessity of OCT4 and CDX2 for early development and gene expression involved in differentiation of inner cell mass and trophectoderm lineages in bovine embryos. Cell Reprogram. 2016;18: 309-18. https://doi.org/10.1089/cell.2015.0081.

25. Negrón-Pérez VM, Hansen PJ. Role of yes-associated protein 1, angiomotin and mitogen activated kinase kinase 1/2 in development of the bovine blastocyst. Biol Reprod. 2017;2018:doi: https://doi.org/10.1093/biolre/iox172.

26. Simmet K, Zakhartchenko V, Philippou-Massier J, Blum H, Klymiuk N, Wolf E. OCT4/POU5F1 is required for NANOG expression in bovine blastocysts. Proc Natl Acad Sci. 2018;115:2770-5. https://doi.org/10.1073/pnas.1718833115.

27. Akizawa H, Kobayashi K, Bai H, Takahashi M, Kagawa S, Nagatomo H, et al. Reciprocal regulation of TEAD4 and CCN2 for the trophectoderm development of the bovine blastocyst. Reproduction. 2018;155:563-71.

28. Shin K, Straight S, Margolis B. PATJ regulates tight junction formation and polarity in mammalian epithelial cells. J Cell Biol. 2005;168:705-11. https://doi.org/10.1083/jcb.200408064.

29. Moriwaki K, Tsukita S, Furuse M. Tight junctions containing claudin 4 and 6 are essential for blastocyst formation in preimplantation mouse embryos. Dev Biol. 2007;312:509-22. https://doi.org/10.1016/j.ydbio.2007.09.049.

30. Park S, DiMaio TA, Scheef EA, Sorenson CM, Sheibani N. PECAM1 regulates proangiogenic properties of endothelial cells through modulation of cellcell and cell-matrix interactions. Am J Physiol Cell Physiol. 2010;299:C146884. https://doi.org/10.1152/ajpcell.00246.2010.

31. Charfi C, Levros L-C, Edouard E, Rassart E. Characterization and identification of PARM1 as a new potential oncogene. Mol Cancer. 2013;12:84. https://doi.org/10.1186/1476-4598-12-84.

32. Maurer ME, Cooper JA. Endocytosis of megalin by visceral endoderm cells requires the Dab2 adaptor protein. J Cell Sci. 2005;118:5345-55. https://doi.org/10.1242/JCS.02650.

33. Fleming TP, Goodall H. Endocytic traffic in trophectoderm and polarised blastomeres of the mouse preimplantation embryo. Anat Rec. 1986;216: 490-503. https://doi.org/10.1002/ar.1092160406.

34. Meng F, Forrester-Gauntlett B, Turner P, Henderson H, Oback B. Signal inhibition reveals JAKSSTAT3 pathway as critical for bovine inner cell mass development1. Biol Reprod. 2015;93. https://doi.org/10.1095/biolreprod.115.134254.

35. Do DV, Ueda J, Messerschmidt DM, Lorthongpanich C, Zhou Y, Feng B, et al. A genetic and developmental pathway from STAT3 to the OCT4-NANOG circuit is essential for maintenance of ICM lineages in vivo. Genes Dev. 2013; 27:1378-90. https://doi.org/10.1101/gad.221176.113. 
36. Chung JT, Tosca L, Huang TH, Xu L, Niwa K, Chian RC. Effect of polyvinylpyrrolidone on bovine oocyte maturation in vitro and subsequent fertilization and embryonic development. Reprod BioMed Online. 2007;15:198-207.

37. Fischer-Brown $A E$, Lindsey $B R$, Ireland $F A$, Northey DL, Monson RL, Clark SG, Wheeler MB, Kesler DJ, Lane SJ, Weigel KA, Rutledge JJ. Embryonic disc development and subsequent viability of cattle embryos following culture in two media under two oxygen concentrations. Reprod Fertil. Dev. 2004;16:787-93.

38. Loureiro B, Block J, Favoreto MG, Carambula S, Pennington KA, Ealy AD, Hansen PJ. Consequences of conceptus exposure to colony-stimulating factor 2 on survival, elongation, interferon-t secretion, and gene expression. Reproduction. 2011;141:617-24. https://doi.org/10.1530/REP-10-0511.

39. van Soom A, Ysebaert MT, de Kruif A. Relationship between timing of development, morula morphology, and cell allocation to inner cell mass and trophectoderm in in vitro-produced bovine embryos. Mol Reprod Dev. 1997:47:47-56

40. Atienza-Samols SB, Pine PR, Sherman MI. Effects of tunicamycin upon glycoprotein synthesis and development of early mouse embryos. Dev Biol. 1980;79:19-32. https://doi.org/10.1016/0012-1606(80)90070-6.

41. Zolini AM, Ortiz WG, Estrada-Cortes E, Ortega MS, Dikmen S, Sosa F, et al. Interactions of human chorionic gonadotropin with genotype and parity on fertility responses of lactating dairy cows. J Dairy Sci. 2019;102:846-58. https://doi.org/10.3168/jds.2018-15358.

42. Denicol AC, Dobbs KB, McLean KM, Carambula SF, Loureiro B, Hansen PJ. Canonical WNT signaling regulates development of bovine embryos to the blastocyst stage. Sci Rep. 2013;3:1266. https://doi.org/10.1038/srep01266.

43. Ortega MS, Wohlgemuth S, Tribulo P, Siqueira LGB, Null DJ, Cole JB, et al. A single nucleotide polymorphism in COQ9 affects mitochondrial and ovarian function and fertility in Holstein cows. Biol Reprod. 2017;96:652-63. https:// doi.org/10.1093/biolre/iox004.

44. Denicol AC, Block J, Kelley DE, Pohler KG, Dobbs KB, Mortensen CJ, Ortega MS, Hansen PJ. The WNT signaling antagonist Dickkopf-1 directs lineage commitment and promotes survival of the preimplantation embryo. FASEB J. 2014;28:3975-86. https://doi.org/10.1096/fj.14-253112.

45. Negrón-Pérez VM, Hansen PJ. The bovine embryo hatches from the zona pellucida through either the embryonic or abembryonic pole. J Assist Reprod Genet. 2017;34:725-31. https://doi.org/10.1007/s10815-017-0933-3.

\section{Publisher's Note}

Springer Nature remains neutral with regard to jurisdictional claims in published maps and institutional affiliations.

Ready to submit your research? Choose BMC and benefit from:

- fast, convenient online submission

- thorough peer review by experienced researchers in your field

- rapid publication on acceptance

- support for research data, including large and complex data types

- gold Open Access which fosters wider collaboration and increased citations

- maximum visibility for your research: over $100 \mathrm{M}$ website views per year

At BMC, research is always in progress.

Learn more biomedcentral.com/submissions 